\title{
Comparison of osteogenic differentiation ability between bone marrow-derived mesenchymal stem cells and adipose tissue-derived mesenchymal stem cells
}

\author{
Paulina Kazimierczak', Ewa Syta', Agata Przekora', Grażyna Ginalska' \\ ${ }^{1}$ Chair and Department of Biochemistry and Biotechnology, Medical University of Lublin, Poland \\ Kazimierczak P, Syta E, Przekora A, Ginalska G. Comparison of osteogenic differentiation ability between bone marrow-derived mesenchymal \\ stem cells and adipose tissue-derived mesenchymal stem cells. Med Og Nauk Zdr. 2018; 24(2): 101-106. doi: 10.26444/monz/92078
}

\begin{abstract}
An important clinical problem is the fast restoration of large bone defects caused by trauma, tumour resection, infections, or skeletal anomaly. Autografts and allografts are commonly known approaches to bone repair, however, they have a lot of limitations. Bone tissue engineering has been considered as the alternative solution to bone rebuilding when natural grafts cannot be used. The primary model of bone tissue engineering comprises three elements: scaffold, growth factors, and stem or progenitor cells. The role of cells is to differentiate into osteoblasts and to form a bone extracellular matrix. Mesenchymal stem cells (MSCs) possess the mentioned features which make them a promising tool in supporting bone restoration process. MSCs are present in multiple tissues, including bone marrow and adipose tissue. This study presents the similarities and differences between bone marrow-derived mesenchymal stem cells (BMDSCs) and adipose tissue-derived mesenchymal stem cells (ADSCs). The study also compares the osteogenic potential of these cells, based on available literature. The presented comparison showed that both BMDSCs and ADSCs possess osteogenic ability under in vitro and in vivo conditions. However, most of the in vitro research confirmed the inferior osteogenic potential of ADSCs, compared to BMDSCs. Contrariwise, the in vivo studies revealed more controversies on this point in the scientific community; namely, some research studies considered the ADSCs as the promising alternative for BMDSCs which have been successfully used to-date for bone tissue engineering applications.
\end{abstract}

\section{Key words}

bone formation, stromal cells, tissue engineering, bone tissue

\section{INTRODUCTION AND OBJECTIVE}

Restoration of large bone defects is still a challenge for regenerative medicine. The bone defects may be caused by trauma, tumour resection, infections, skeletal anomaly, or by impaired regenerative process. Due to the increase in life expectancy, the reduction or treatment of bone healing complications is becoming more important. Regeneration by means of autograft or allograft provides great effects, but it has a number of limitations. Autografts are limited by morbidity due to surgical harvesting procedures and the potential risk of infection, chronic pain, and haematoma at the site of donation. However, autografts are still considered as the gold standard because they are non-immunogenic and histocompatible. The use of allografts also has constraints, e.g. by tissue matching, the risk of infection or disease transmitting. The limited use of auto- and allografts has driven the development of research on a broad diversity of biomaterials to be applied as scaffolds. Bone tissue engineering has been considered as the alternative solution to bone rebuilding. One of the crucial purposes of this approach is to seed patient osteoprogenitor cells onto biomaterial and to enhance osteogenic differentiation of stem cells within the scaffold in in vitro conditions in order to obtain a clinically applicable bone construct [1-2].

Address for correspondence: Paulina Kazimierczak, Katedra i Zakład Biochemii i Biotechnologii, Uniwersytet Medyczny w Lublinie, Chodźki 1, 20-093 Lublin, Poland

E-mail: paulina.kazimierczak@umlub.pl

Received: 18 April 2018; accepted: 8 June 2018
The primary model of bone tissue engineering comprises three elements: scaffold, growth factors, and stem or progenitor cells. The three-dimensional porous scaffold promotes a new tissue formation by providing a surface, void volume, and mechanical stability that supports osteoblastic cells' attachment, proliferation, migration, and desired differentiation. Growth factors stimulate cellular growth, proliferation, and differentiation at the site of implantation, whereas the role of osteoprogenitor/stem cells is to accelerate the bone regeneration process by their differentiation into osteoblasts capable of forming a bone extracellular matrix (ECM). The production of clinically applicable bone scaffold in vitro needs a great number of cells $[1,3,4]$. Embryonic stem cells (ESCs) and adult stem cells possess some appropriate features for bone tissue engineering applications. Among the potential candidate cells, ESCs are desirable in view of their pluripotency, but their application is limited due to the ethical issue. Additionally, scientists have found that transplantation of ESCs led to teratoma formation in the animal model [5-6].

Mesenchymal stem cells (MSCs) are adult stem cells having the ability of self-renewal and multi-lineage differentiation, including osteogenic capacity [4]. Moreover, MSCs possess lack of immunogenicity [1]. About 50 years ago, Friedenstein et al. discovered MSCs in bone marrow tissue with adherence phenotype and fibroblast-like shape in culture conditions [7]. Since then, it has been proved that MSCs are also present in multiple tissues, including trabecular bone [8], synovium [9], skeletal muscle [10], periosteum [11], among others. Bone marrow and adipose tissue are the well-known and studied 
origin of MSCs, which are able to form inter alia bone and cartilage.

The prsented study describes the similarities and differences between BMDSCs and ADSCs, and compares the osteogenic potential of these cells, based on available literature.

\section{ACTUAL STATE OF KNOWLEDGE}

Characterization and isolation of mesenchymal stem cells. To define human MSCs, the Mesenchymal and Tissue Stem Cell Committee of the International Society for Cellular Therapy suggests three major requirements for this population of cells. Firstly, MSCs must be adherent to plastic when cultivated under standard culture condition. The second criteria is expression of CD73, CD90, CD105, and lack of expression of CD45, CD34, CD11b or CD14, CD19 or CD79alpha and HLA-DR surface markers. Finally, MSCs must be capable of differentiation into osteoblasts, adipocytes, and chondroblasts under in vitro conditions [12]. These features are important for all MSCs, although slight discrepancies may occur in MSCs isolated from different tissue sources; thus, BMDSCs and ADSCs may show minor differences in the expression of surface markers, e.g. unlike BMDSCs, ADSCs express CD49d marker, whereas BMDSCs express CD106 marker, which is absent from the surface of ADSCs [13].

At present, bone marrow is a very common source of MSCs, which were successfully isolated from different species, e.g. mouse, rat, pig, dog, and human [14-17]. A variety methodologies have been used for the isolation and expansion of BMDSCs, including low- and high-density culture systems [17], frequent culture medium changes [19] or enzymatic digestion approach [20]. It is worth noting that the type of isolation method used, as well as the origin and age of the donor, can significantly affect the proliferation potential of the isolated BMDSCs. Moreover, researchers have observed differences in the proliferation rates of stem cells isolated from various bone areas [21].

Bone marrow aspirates contain some haematopoietic cells, which are also adherent to the plastic dishes; however, during the sub-culturing step these cells are removed, and the remaining culture contains only adherent BMDSCs revealing a spindle-shape appearance. On average, there are $6 \times 10^{6}$ nucleated cells in 1 milliliter of bone marrow aspirate, and stem cells constitute about $0.001 \%-0.01 \%$ of all nucleated cells $[17,22]$. The low yield of stem cells' isolation from bone marrow aspirates, as well as painful bone marrow biopsy and aspiration, are the main drawbacks to the use of BMDSCs in bone tissue engineering applications. Therefore, researchers have been recently sought an alternative source of stem cells.

Adipose tissue is considered as an attractive alternative source of MSCs due to its easy availability in large quantities in the living organism. ADSCs can be obtained from adipose tissue collected by lipectomy and liposuction. These methods of cells' harvesting are simple, repeatable and carry low risk of possible complications. The adipose tissue is enzymatically digested followed by centrifugation to obtain a cell pellet called stromal vascular fraction (SVF) [23]. Adipose tissuederived SVF is a heterogeneous cells' population that contains stromal cells, endothelial cells and their progenitors, vascular smooth muscle cells, leukocytes, haematopoietic progenitors, pericytes, preadipocytes, and ADSCs. MSCs occurring in SVF have the plastic adherent character under standard culture condition. Washing procedure, immunomagnetic separation or flow cytometric sorting may be used for purification of ADSCs from SVF. However, specific cell surface markers can be modified by the cell culturing procedure and by the number of passages [2]. ADSCs may differentiate not only into adipocytes, osteoblasts, and chondrocytes but also into myocytes, hepatocytes, endothelial cells and neuronal cells [13]. The cells' isolation yield from lipoaspirate tissue is $2 \times 10^{6}$ cells per 1 gram of adipose tissue, and stem cells constitute about $10 \%$ of all nucleated cells [24]. Stem cells derived from bone marrow and adipose tissue initially appear as adherent, single colony clusters known as fibroblast colony-forming units (CFU-F). Importantly clonogenic assays indicated that there are $5000 \mathrm{CFU}-\mathrm{F}$ in 1 gram of adipose tissue, whereas 1 milliliter of bone marrow contains only 100-1000 CFU-F. Therefore, the stem cells' isolation yield from adipose tissue is higher than from bone marrow [25].

In contrast to ADSCs, there is a necessity to perform a lot of in vitro passages of BMDSCs in order to obtain a sufficient amount of osteoprogenitor cells for small bone defect repair. Furthermore, long-term in vitro culture of BMDSCs is timeconsuming and may increase the risk of contamination and gene mutation [26].

Osteogenic differentiation potential of MSCs in vitro. Osteogenic differentiation is a multi-stage process which involves the proliferation, ECM maturation, and ECM mineralization phase. The universal protocol for in vitro osteogenic differentiation of MSCs requires long-term culture (2-3 weeks) of cells in the presence of a growth medium containing dexamethasone, beta-glycerol phosphate and ascorbic acid. These reagents are used in appropriate concentrations, so as to create the physiological state under in vitro conditions [27]. Since the discovery of BMDSCs and ADSCs osteogenic differentiation in vitro, considerable development has been made in the direction of the use of these cells as an optimal source for bone regeneration. One of the approaches of modern regenerative medicine involves the direct administration of stem cells into scaffolds in order to generate bone graft in vitro [2]. In this subsection, the osteogenic capacity in vitro is compared between BMDSCs and ADSCs, based on the literature (Tab. 1).

Zuk et al. found that ADSCs isolated from adipose tissue by suction-assisted lipectomy and maintained in vitro for the extended time, had lower levels of senescence and more stable population doubling in comparison to BMDSCs. In the presence of lineage-specific induction factors, ADSCs could differentiate into adipogenic, myogenic, chondrogenic, and osteogenic cells [28]. De Ugarte et al. demonstrated that there were no significant differences between BMDSCs and ADSCs concerning their osteogenic potential, cell senescence, adhesion capacity, growth kinetics, and gene transduction efficiency. Osteogenic differentiation was detected by evaluation of alkaline phosphatase (ALP) activity and calcium content. De Ugarte et al. showed that ALP activity was equal to $0.08 \pm 0.07$ and $0.10 \pm 0.12 \mathrm{nmol}$ p-nitrophenol produced/min per $1 \mu \mathrm{g}$ protein, and total calcium content was $42 \pm 55$ and $33 \pm 38 \mathrm{mM}$ Ca per $1 \mu \mathrm{g}$ protein in BMDSCs and ADSCs, respectively [29]. Likewise, Kern et al. observed no distinct differences between BMDSCs and ADSCs in the osteogenic differentiation capacity [26]. Interestingly, Przekora et al. demonstrated by using the 
Table 1. Comparison of in vitro osteogenic ability between bone marrow-derived mesenchymal stem cells and adipose tissue-derived mesenchymal stem cells

\begin{tabular}{|c|c|c|c|c|}
\hline References & Osteogenic potential & Growth substrate & Technique of markers' detection & Osteogenic medium composition \\
\hline $\begin{array}{l}\text { De Ugarte } \\
\text { et al. [29] }\end{array}$ & $\mathrm{BMDSC}=\mathrm{ADSC}$ & $\begin{array}{l}\text { tissue culture polystyrene } \\
\text { dish }\end{array}$ & $\begin{array}{l}\text { ALP activity } \\
\text { (colorimetric assay) } \\
\text { calcium content (colorimetric assay) }\end{array}$ & $\begin{array}{l}50 \mu \mathrm{M} \text { ascorbic acid-2-phosphate } \\
10 \mathrm{mM} \text {-glycerolphosphate } \\
0,1 \mu \mathrm{M} \text { dexamethasone }\end{array}$ \\
\hline $\begin{array}{l}\text { Kern et al. } \\
{[26]}\end{array}$ & $\mathrm{BMDSC}=\mathrm{ADSC}$ & $\begin{array}{l}\text { tissue culture polystyrene } \\
\text { dish }\end{array}$ & $\begin{array}{l}\text { ALP activity (histochemical staining) } \\
\text { bone mineral content (von Kossa staining) }\end{array}$ & $\begin{array}{l}0.2 \mathrm{mM} \text { ascorbate-2-phosphate } \\
10 \mathrm{mM} \beta \text {-glycerolphosphate } \\
100 \mathrm{nM} \text { dexamethasone }\end{array}$ \\
\hline \multirow{2}{*}{$\begin{array}{l}\text { Przekora } \\
\text { et al. [30] }\end{array}$} & BMDSC $>$ ADSC & $\begin{array}{l}\text { chitosan/ } \beta-1,3 \text {-glucan/ } \\
\text { hydroxyapatite }\end{array}$ & \multirow{2}{*}{$\begin{array}{l}\text { Col I and OC synthesis } \\
\text { (immunofluorescence staining) }\end{array}$} & \multirow{2}{*}{$\begin{array}{l}50 \mu \mathrm{g} / \mathrm{mL} \text { ascorbic acid-2-phosphate } \\
10 \mathrm{mM} \beta \text {-glycerolphosphate } \\
10 \mathrm{nM} \text { dexamethasone }\end{array}$} \\
\hline & $\mathrm{BMDSC}=\mathrm{ADSC}$ & $\begin{array}{l}\text { tissue culture glass } \\
\text { coverslip }\end{array}$ & & \\
\hline Im et al. [32] & BMDSC $>$ ADSC & $\begin{array}{l}\text { tissue culture polystyrene } \\
\text { dish }\end{array}$ & $\begin{array}{l}\text { ALP activity (histochemical staining) } \\
\text { bone mineral content (von Kossa staining) }\end{array}$ & $\begin{array}{l}50 \mu \mathrm{M} \text { ascorbic acid-2-phosphate } \\
10 \mathrm{mM} \beta \text {-glycerolphosphate } \\
0.1 \mu \mathrm{M} \text { dexamethasone }\end{array}$ \\
\hline Liu et al. [33] & $\mathrm{BMDSC}>\mathrm{ADSC}$ & $\begin{array}{l}\text { tissue culture polystyrene } \\
\text { dish }\end{array}$ & bone mineral content (alizarin red staining) & $\begin{array}{l}50 \mu \mathrm{M} \text { ascorbic acid-2-phosphate } \\
10 \mathrm{mM} \text {-glycerolphosphate } \\
0.1 \mu \mathrm{M} \text { dexamethasone }\end{array}$ \\
\hline $\begin{array}{l}\text { Shafiee et al. } \\
\text { [34] }\end{array}$ & BMDSC $>$ ADSC & $\begin{array}{l}\text { tissue culture polystyrene } \\
\text { dish }\end{array}$ & $\begin{array}{l}\text { ALP activity (colorimetric assay) } \\
\text { calcium content (colorimetric assay) } \\
\text { ALP, Col I, Runx2, ON, OC, BMP-2 (RT-PCR) }\end{array}$ & $\begin{array}{l}0.2 \mathrm{mM} \text { ascorbic acid-2-phosphate } \\
10 \mathrm{mM} \text { ß-glycerolphosphate } \\
10 \mathrm{nM} \text { dexamethasone }\end{array}$ \\
\hline $\begin{array}{l}\text { Vishnubalaji } \\
\text { et al. [35] }\end{array}$ & BMDSC $>$ ADSC & $\begin{array}{l}\text { tissue culture polystyrene } \\
\text { dish }\end{array}$ & $\begin{array}{l}\text { ALP activity (histochemical staining) } \\
\text { bone mineral content (von Kossa staining, alizarin red staining) } \\
\text { calcium content (colorimetric assay) } \\
\text { ALP, Col I, Runx2, ON, OC, BMP-2 (RT-PCR) }\end{array}$ & $\begin{array}{l}50 \mu \mathrm{g} / \mathrm{mL} \text { ascorbic acid-2-phosphate } \\
10 \mathrm{mM} \text {-glycerolphosphate } \\
10 \mathrm{nM} \text { dexamethasone } \\
10 \mathrm{nM} \text { calcitriol }\end{array}$ \\
\hline
\end{tabular}

immunofluorescent technique that ADSCs aspirated under low negative pressure $(-200 \mathrm{mmHg})$ during a liposuction procedure, produced greater amounts of type I collagen (Col I), compared to ADSCs which were aspirated under high negative pressure $(-700 \mathrm{mmHg})$, but a similar quantity of Col I, compared to BMDSCs [30].

Furthermore, Izadpanah et al. evaluated the differentiation potential of BMDSCs and ADSCs, derived from humans and rhesus monkeys. Early populations of human and rhesus monkey MSCs presented similar osteogenic differentiation capability, where the percent of colonies which were liable to osteogenic differentiation extended between $50 \%-65 \%$ of the total colonies in all MSC types. Nevertheless, the percent of MSC colonies revealing osteogenic differentiation ability was reduced to $20 \%-25 \%$ in rhesus monkey ADSCs and human BMDSCs at passage 20, and to 30\%-35\% in human ADSCs and rhesus monkey BMDSCs at passage 30 [31]. Im et al. also showed, using ALP staining and bone mineral staining by von Kossa, that ADSCs had lower osteogenic potential compared with BMDSCs [32]. Liu et al. proved that recruitment of different late differentiation factors affected BMDSCs which differentiated more successfully into bone and cartilage, whereas ADSCs differentiated preferably into adipocytes [33]. Similarly, Shafiee et al. demonstrated that during osteogenic differentiation, BMDSCs had higher ALP activity and mineralization capacity than ADSCs. Although ADSCs produced higher amounts of Col I, osteonectin $(\mathrm{ON})$ and bone morphogenic protein-2 (BMP2 ) in the undifferentiated state, these proteins were higher expressed in BMDSCs during osteogenic differentiation. Moreover, during induction of the differentiation process, BMDSCs showed higher levels of ALP, osteocalcin (OC), and Runt-related transcription factor 2 (Runx2), compared to ADSCs [34]. The superior osteogenic potential of BMDSCs compared to ADSCS was also proved by Vishnubalaji et al., who showed, using Real-Time PCR technique, that relative genes' expression for ALP, OC, and osteopontin (OP) was lower in ADSCs compared with BMDSCs [35].

Osteogenic differentiation potential of MSCs in vivo. To adequately confirm the osteogenic potential of the MSCs in the area of clinical applications, there is need to verify results obtained with in vitro studies by performing reliable in vivo experiments. There are many research papers describing studies on animal models in the available literature (Tab. 2). Hayashi et al. compared new bone formation in rats by subcutaneous implantation of hydroxyapatite biomaterials seeded with rat stem cells (ADSCs and BMDSCs). Six weeks after implantation, composites were harvested and subjected to micro-computed tomography $(\mu \mathrm{CT})$ and histological analyses. The experiment demonstrated that composites seeded with BMDSCs to a greater extent promoted formation of new bone than composites seeded with ADSCs [36]. Niemeyer et al. presented a comparison of osteogenic potential of ovine BMDSCs and ADSCs which were cultured on mineralized collagen sponges. In addition, they evaluated the influence of platelet-rich plasma (PRP) on the osteogenic ability of ADSCs. Scaffolds seeded with the stem cells were implanted into the sheep tibia. Twenty-six weeks after implantation, a radiographic evaluation was performed which showed a superior new bone formation process within the scaffold seeded with BMDSCs, compared to the scaffold seeded with ADSCs. However, the ADSCloaded scaffold applied in combination with PRP revealed a similar ability to new bone formation as the scaffold seeded with BMDSCs [37]. Wen et al. compared bone regeneration process within cranial defects of rats using BMDSCs and ADSCs cultured on collagen gel. They revealed, by means of histological and X-ray analysis, similar new bone formation process within collagen gel, regardless of the type of MSCs seeded (BMDSCs and ADSCs) [38]. Kang et al. used in their experiments BMDSCs or ADSCs combined with $\beta$-tricalcium 
Table 2. Comparison of in vivo osteogenic ability between bone marrow-derived mesenchymal stem cells and adipose tissue-derived mesenchymal stem cells.

\begin{tabular}{llll}
\hline References & Osteogenic potential & Analytical method & Animal model and type of scaffold \\
\hline Hayashi et al. [36] & BMDSC>ADSC & $\begin{array}{l}\mu C T \\
\text { histological analysis }\end{array}$ & $\begin{array}{l}\text { rat (subcutaneous) } \\
\text { hydroxyapatite }\end{array}$ \\
\hline Niemeyer et al. [37] & $\begin{array}{l}\text { BMDSC }>\text { ADSC } \\
\text { BMDSC=ADSC+PRP }\end{array}$ & $\begin{array}{l}\text { radiographic analysis } \\
\text { histological analysis }\end{array}$ & $\begin{array}{l}\text { sheep (tibial defect) } \\
\text { collagen sponge }\end{array}$ \\
\hline Wen et al. [38] & BMDSC=ADSC & $\begin{array}{l}\text { X-ray } \\
\text { histological analysis }\end{array}$ & $\begin{array}{l}\text { rat (calvarial bone defect) } \\
\text { collagen gel }\end{array}$ \\
\hline Kang et al. [39] & BMDSC=ADSC & $\begin{array}{l}\text { radiographic analysis histological analysis } \\
\text { histomorphometric analysis }\end{array}$ & $\begin{array}{l}\text { dog (radial bone defect) } \\
\text { tricalcium phosphate }\end{array}$ \\
\hline Stockmann et al. [40] & BMDSC=ADSC & microradiography histomorphometric analysis & $\begin{array}{l}\text { pig (calvarial bone defect) } \\
\text { bovine type I collagen }\end{array}$ \\
\hline Brennan et al. [41] & BMDSC>ADSC & $\begin{array}{l}\text { histological analysis } \\
\text { histomorphometric analysis }\end{array}$ & $\begin{array}{l}\text { nude mouse (subcutaneous) } \\
\text { biphasic calcium phosphate }\end{array}$ \\
\hline Fennema et al. [2] & BMDSC>ADSC & histological analysis & $\begin{array}{l}\text { nude mouse (subcutaneous) } \\
\text { calcium phosphate ceramic scaffolds and a platelet-rich plasma gel }\end{array}$
\end{tabular}

phosphate materials, which were implanted into segmental bone defects in dogs for twenty weeks. Unlike the abovementioned researchers, they reported similar osteogenic capacities of BMDSCs and ADSCs, indicating that ADSCs can potentially be used instead of BMDSCs for bone tissue engineering [39]. Similarly, Stockmann et al., who studied the regeneration of pig monocortical calvarial bone defect using collagen scaffolds seeded with stem cells, demonstrated that the new bone formation and the healing rate were not significantly different between BMDSCs and ADSCs [40].

Brennan et al. compared the osteogenic potential of human xenofree-expanded ADSCs and BMDSCs in a nude mouse model of ectopic bone formation. MSCs were seeded onto biphasic calcium phosphate biomaterials and subcutaneously implanted for eight weeks. The results showed that ADSCs failed to form ectopic bone, but revealed enhanced in vivo neovascularization compared with BMDSCs [41]. Fennema et al. investigated whether aggregation of BMDSCs, ADSCs, and SVF cells could improve ectopic bone formation. The ectopic bone formation was estimated after implantation of tissue engineered constructs (spheroids of MSCs combined with calcium phosphate ceramic scaffolds and a platelet rich plasma gel) in immunodeficient mice for six weeks. The following variants were implanted: constructs with ADSCs, constructs with BMDSCs, constructs with SVF cells (with and without rhBMP-2 - morphogenetic growth factors). In vivo study showed that ADSCs and SVF cells both formed ectopic bone in the absence of rhBMP-2. BMDSCs formed a new bone in the highest amount, followed by SVF + rhBMP-2, ADSCs and SVF. Moreover, ADSCs showed inferior spheroid formation compared to BMDSCs. Researchers discovered that aggregation of ADSCs induced a meaningful positive regulation of osteogenic markers' gene expression, such as ALP and Col I, in comparison to non-aggregated ASDCs. Aggregation can boost ectopic bone tissue formation by ADSCs, but is less effective than rhBMP-2 [42].

\section{SUMMARY}

This study presented the comparison of osteogenic potential between BMDSCs and ADSCs, based on available literature. Most of the in vitro research confirmed the inferior bone formation capacity of ADSCs; however, several reports describing long-term studies on osteogenic differentiation of BMDSCs and ADSCs using in vivo models, revealed more divergent opinions on this matter. Namely, a number of researchers considered the ADSCs as the potential substitute of BMDSCs for bone tissue engineering applications. Moreover, they indicated that the osteogenic potential of ADSCs, to some extent, may be enhanced by the combination of ADSC-loaded scaffold with PRP. The opportunity to use ADSCs as an alternative to BMDSCs for bone restoration is of great interest due to easy accessibility and the abundance of adipose tissue, high stem cells' isolation yield, and rapid rate of ADSC proliferation in vitro. Nevertheless, further studies are necessary to investigate the clinical applications of ADSCs. This can lead to the development of new cellular therapies that may be used in the clinical treatments of various bone defects.

\section{REFERENCES}

1. Rose FR, Oreffo RO. Bone tissue engineering: hope vs hype. Biochem Biophys Res Commun. 2002; 292(1): 1-7.

2. Romagnoli C, Brandi ML. Adipose mesenchymal stem cells in the field of bone tissue engineering. World J Stem Cells. 2014; 6(2): 144-152.

3. Fröhlich M, Grayson WL, Wan LQ, Marolt D, Drobnic M, VunjakNovakovic G. Tissue engineered bone grafts: biological requirements, tissue culture and clinical relevance. Curr Stem Cell Res Ther. 2008; 3(4): 254-264.

4. Muschler GF, Nakamoto C, Griffith LG. Engineering principles of clinical cell-based tissue engineering. J Bone Joint Surg Am. 2004; 86-A(7): 1541-1558.

5. Kuhn LT, Liu Y, Boyd NL, Dennis JE, Jiang X, Xin X, et al. Developmentallike bone regeneration by human embryonic stem cell-derived mesenchymal cells. Tissue Eng Part A. 2014; 20(1-2): 365-377.

6. Daar AS, Bhatt A, Court E, Singer PA. Stem cell research and transplantation: science leading ethics. Transplant Proc. 2004; 36(8): 2504-2506.

7. Friedenstein AJ, Chailakhjan RK, Lalykina KS. The development of fibroblast colonies in monolayer cultures of guinea-pig bone marrow and spleen cells. Cell Tissue Kinet. 1970; 3(4): 393-403.

8. Nöth U, Osyczka AM, Tuli R, Hickok NJ, Danielson KG, Tuan RS. Multilineage mesenchymal differentiation potential of human trabecular bone-derived cells. J Orthop Res. 2002; 20(5): 1060-1069.

9. De Bari C, Dell'Accio F, Tylzanowski P, Luyten FP. Multipotent mesenchymal stem cells from adult human synovial membrane. Arthritis Rheum. 2001; 44(8): 1928-1942.

10. Bosch P, Musgrave DS, Lee JY, Cummins J, Shuler T, Ghivizzani TC, et al. Osteoprogenitor cells within skeletal muscle. J Orthop Res. 2000; 18(6): 933-944. 
11. Nakahara H, Goldberg VM, Caplan AI. Culture-expanded human periosteal-derived cells exhibit osteochondral potential in vivo. J Orthop Res. 1991; 9(4): 465-476.

12. Dominici M, Le Blanc K, Mueller I, Slaper-Cortenbach I, Marini F, Krause D, et al. Minimal criteria for defining multipotent mesenchymal stromal cells. The International Society for Cellular Therapy position statement. Cytotherapy. 2006; 8(4): 315-317.

13. Lindroos B, Suuronen R, Miettinen S. The potential of adipose stem cells in regenerative medicine. Stem Cell Rev. 2011; 7(2): 269-291.

14. Meirelles Lda S, Nardi NB. Murine marrow-derived mesenchymal stem cell: isolation, in vitro expansion, and characterization. Br J Haematol. 2003; 123(4): 702-711.

15. Lennon DP, Caplan AI. Isolation of rat marrow-derived mesenchymal stem cells. Exp Hematol. 2006; 34(11): 1606-1607.

16. Ringe J, Kaps C, Schmitt B, Büscher K, Bartel J, Smolian H, et al. Porcine mesenchymal stem cells. Induction of distinct mesenchymal cell lineages. Cell Tissue Res. 2002; 307(3): 321-327.

17. Takemitsu H, Zhao D, Yamamoto I, Harada Y, Michishita M, Arai T. Comparison of bone marrow and adipose tissue-derived canine mesenchymal stem cells. BMC Vet Res. 2012; 8: 150.

18. Eslaminejad MB, Nadri S. Murine mesenchymal stem cell isolated and expanded in low and high d6ensity culture system: surface antigen expression and osteogenic culture mineralization. In Vitro Cell Dev Biol Anim. 2009; 45(8): 451-459.

19. Soleimani M, Nadri S. A protocol for isolation and culture of mesenchymal stem cells from mouse bone marrow. Nat Protoc. 2009; 4(1): 102-106.

20. Siclari VA, Zhu J, Akiyama K, Liu F, Zhang X, Chandra A, et al. Mesenchymal progenitors residing close to the bone surface are functionally distinct from those in the central bone marrow. Bone. 2013; 53(2): 575-586.

21. Akintoye SO, Lam T, Shi S, Brahim J, Collins MT, Robey PG. Skeletal site-specific characterization of orofacial and iliac crest human bone marrow stromal cells in same individuals. Bone. 2006; 38(6): 758-768.

22. Pittenger MF, Mackay AM, Beck SC, Jaiswal RK, Douglas R, Mosca JD, et al. Multilineage potential of adult human mesenchymal stem cells. Science. 1999; 284(5411): 143-147.

23. Bunnell BA, Flaat M, Gagliardi C, Patel B, Ripoll C. Adipose-derived stem cells: isolation, expansion and differentiation. Methods. 2008; 45(2): 115-220.

24. Aust L, Devlin B, Foster SJ, Halvorsen YD, Hicok K, du Laney T, et al. Yield of human adipose-derived adult stem cells from liposuction aspirates. Cytotherapy. 2004; 6(1): 7-14.

25. Strem BM, Hicok KC, Zhu M, Wulur I, Alfonso Z, Schreiber RE, et al. Multipotential differentiation of adipose tissue-derived stem cells. Keio J Med. 2005; 54(3): 132-141.

26. Kern S, Eichler H, Stoeve J, Klüter H, Bieback K. Comparative analysis of mesenchymal stem cells from bone marrow, umbilical cord blood, or adipose tissue. Stem Cells. 2006; 24(5): 1294-1301.

27. Eslaminejad MB, Taghiyar L. Study of the structure of canine mesenchymal stem cell osteogenic culture. Anat Histol Embryol. 2010; 39(5): 446-455.

28.Zuk PA, Zhu M, Mizuno H, Huang J, Futrell JW, Katz AJ, et al. Multilineage cells from human adipose tissue: implications for cellbased therapies. Tissue Eng. 2001; 7(2): 211-228.
29. De Ugarte DA, Morizono K, Elbarbary A, Alfonso Z, Zuk PA, Zhu M, et al. Comparison of multi-lineage cells from human adipose tissue and bone marrow. Cells Tissues Organs. 2003; 174(3): 101-9.

30. Przekora A, Vandrovcova M, Travnickova M, Pajorova J, Molitor M, Ginalska G, et al. Evaluation of the potential of chitosan/ $\beta$-1,3-glucan/ hydroxyapatite material as a scaffold for living bone graft production in vitro by comparison of ADSC and BMDSC behaviour on its surface. Biomed Mater. 2017; 12(1): 015030.

31.Izadpanah R, Trygg C, Patel B, Kriedt C, Dufour J, Gimble JM, et al. Biologic properties of mesenchymal stem cells derived from bone marrow and adipose tissue. J Cell Biochem. 2006; 99(5): 1285-1297.

32. Im GI, Shin YW, Lee KB. Do adipose tissue-derived mesenchymal stem cells have the same osteogenic and chondrogenic potential as bone marrow-derived cells? Osteoarthritis Cartilage. 2005; 13(10): 845-853.

33. Liu TM, Martina M, Hutmacher DW, Hui JH, Lee EH, Lim B. Identification of common pathways mediating differentiation of bone marrow- and adipose tissue-derived human mesenchymal stem cells into three mesenchymal lineages. Stem Cells. 2007; 25(3): 750-760.

34. Shafiee A, Seyedjafari E, Soleimani M, Ahmadbeigi N, Dinarvand P, Ghaemi N. A comparison between osteogenic differentiation of human unrestricted somatic stem cells and mesenchymal stem cells from bone marrow and adipose tissue. Biotechnol Lett. 2011; 33(6): 1257-1264.

35. Vishnubalaji R, Al-Nbaheen M, Kadalmani B, Aldahmash A, Ramesh T. Comparative investigation of the differentiation capability of bonemarrow- and adipose-derived mesenchymal stem cells by qualitative and quantitative analysis. Cell Tissue Res. 2012; 347(2): 419-427.

36. Hayashi O, Katsube Y, Hirose M, Ohgushi H, Ito H. Comparison of osteogenic ability of rat mesenchymal stem cells from bone marrow, periosteum, and adipose tissue. Calcif Tissue Int. 2008; 82(3): 238-247.

37. Niemeyer P, Fechner K, Milz S, Richter W, Suedkamp NP, Mehlhorn AT, et al. Comparison of mesenchymal stem cells from bone marrow and adipose tissue for bone regeneration in a critical size defect of the sheep tibia and the influence of platelet-rich plasma. Biomaterials. 2010; 31(13): 3572-3579.

38. Wen Y, Jiang B, Cui J, Li G, Yu M, Wang F, et al. Superior osteogenic capacity of different mesenchymal stem cells for bone tissue engineering. Oral Surg Oral Med Oral Pathol Oral Radiol. 2013; 116(5): 324-332.

39. Kang BJ, Ryu HH, Park SS, Koyama Y, Kikuchi M, Woo HM, et al. Comparing the osteogenic potential of canine mesenchymal stem cells derived from adipose tissues, bone marrow, umbilical cord blood, and Wharton's jelly for treating bone defects. J Vet Sci. 2012; 13: 299-310.

40. Stockmann P, Park J, von Wilmowsky C, Nkenke E, Felszeghy E, Dehner JF, et al. Guided bone regeneration in pig calvarial bone defects using autologous mesenchymal stem/progenitor cells - a comparison of different tissue sources. J Craniomaxillofac Surg. 2012; 40(4): 310-320.

41. Brennan MA, Renaud A, Guilloton F, Mebarki M, Trichet V, Sensebé L, et al. Inferior In Vivo Osteogenesis and Superior Angiogeneis of Human Adipose Tissue: A Comparison with Bone Marrow-Derived Stromal Stem Cells Cultured in Xeno-Free Conditions. Stem Cells Transl Med. 2017; 6(12): 2160-2172.

42. Fennema EM, Tchang LAH, Yuan H, van Blitterswijk CA, Martin I, Scherberich A, et al. Ectopic bone formation by aggregated mesenchymal stem cells from bone marrow and adipose tissue: A comparative study. J Tissue Eng Regen Med. 2018; 12: e150-e158. 


\title{
Porównanie zdolności różnicowania osteogennego między mezenchymalnymi komórkami macierzystymi ze szpiku kostnego a mezenchymalnymi komórkami macierzystymi z tkanki tłuszczowej
}

\begin{abstract}
I Streszczenie
Istotnym problemem klinicznym jest szybka rekonstrukcja dużych wad kostnych spowodowanych przez uraz, wycięcie guza, infekcje lub anomalię szkieletu. Autoprzeszczepy oraz alloprzeszczepy to jedne z najbardziej znanych podejść do odbudowy kości, posiadają jednak wiele ograniczeń. Inżynieria tkanki kostnej została uznana za alternatywne rozwiązanie dla odbudowy kości w przypadku, kiedy nie jest możliwe zastosowanie wszczepów naturalnych. Podstawowy model inżynierii tkankowej kości składa się z trzech elementów: rusztowania, czynników wzrostu oraz komórek macierzystych lub prekursorowych. Rola tych komórek polega na różnicowaniu ich w osteoblasty oraz tworzeniu macierzy pozakomórkowej kości. Mezenchymalne komórki macierzyste (MSCs) posiadają wymienione cechy, które czynią je obiecującym narzędziem do wspomagania odbudowy kości. MSCs są obecne w wielu tkankach, m.in. w szpiku kostnym i tkance tłuszczowej. W niniejszym artykule przedstawiamy podobieństwa i różnice pomiędzy mezenchymalnymi komórkami macierzystymi pochodzącymi ze szpiku kostnego (BMDSCs) a mezenchymalnymi komórkami macierzystymi pochodzącymi z tkanki tłuszczowej (ADSCs). Ponadto prezentujemy porównanie potencjału osteogennego tych komórek na podstawie dostępnego piśmiennictwa. Otrzymane zestawienie wykazało, że zarówno BMDSCs, jak i ADSCs posiadają zdolność osteogenną w warunkach in vitro oraz in vivo. Jednakże większość badań in vitro wskazała słabszy potencjał osteogenny ADSCs w porównaniu do BMDSCs. W przeciwieństwie do tego, badania in vivo ujawniły w środowisku naukowym więcej rozbieżnych opinii w tej kwestii. Mianowicie w niektórych pracach badawczych uznano komórki ADSCs za obiecującą alternatywę dla komórek BMDSCs stosowanych dotychczas w inżynierii tkankowej kości.
\end{abstract}

\section{Słowa kluczowe}

kościotworzenie, komórki zrębu, inżynieria tkankowa, tkanka kostna 